\title{
Analisis peran pembiayaan BMT Syariah Al-Azhaar terhadap peningkatan kesejahteraan anggota perspektif Maqashid Syariah
}

\author{
Rahmat Imanto*; Maftukhatusolikhah; Ulil Amri \\ Universitas Islam Negeri Raden Fatah Palembang \\ *E-mail korespodensi: rahmatimanto3@gmail.com
}

\begin{abstract}
This study aimed to analyze the role of financing products at BMT Syariah Al-Azhaar Lubuklinggau city, which was rolled out to members and customers of BMT Syariah in improving customer welfare. This study uses a descriptive qualitative method with a case study approach at BMT Syariah Al-Azhaar, Lubuklinggau City, as a research object. The sample used in this study is the customers/members of BMT Syariah AlAzhaar who get financing products. The data collection of this research used an indepth interview method. The data obtained were then analyzed using descriptive analysis. The results of this study are BMT Syariah Al-Azhaar, through financing, plays a significant role in improving the welfare of its members. Interest is measured using five indicators of the maintenance of basic needs based on the objectives of maqashid sharia, namely the care of religion, the maintenance of the soul, the maintenance of the mind, the maintenance of offspring, and the maintenance of a property. The increase in welfare experienced by members varies. In general, there is an increase in welfare as measured by the five indicators.
\end{abstract}

Keywords: Financing, Baitul Maal wat Tamwil, Welfare

\begin{abstract}
Abstrak
Tujuan dari penelitian ini adalah untuk menganalisis dari Peran produk pembiayaan pada BMT Syariah Al-Azhaar kota Lubuklinggau yang digulirkan kepada anggota dan nasabah BMT Syariah dalam meningkatkan kesejahteraan Nasabah. Penelitian ini menggunakan metode kualitatif deskriptif dengan pendekatan studi kasus pada BMT Syariah Al-Azhaar Kota Lubuklinggau sebagai objek penelitian dan sampel yang digunakan dalam penelitian ini adalah nasabah/anggota BMT Syariah Al-Azhaar yang mendapatkan produk pembiayaan. Pengumpulan data penelitian ini menggunakan metode wawancara secara mendalam data yang didapatkan kemudian dianalisis menggunakan uraian deskriptif. Hasil dari penelitian ini adalah BMT Syariah Al-Azhaar melalui pembiayaan sangat berperan dalam meningkatkan kesejahteraan anggotanya. Kesejahteraan diukur dengan menggunakan 5 indikator pemeliharaan kebutuhan dasar berdasarkan tujuan maqashid syariah yaitu pemeliharaan agama, pemeliharaan jiwa, pemeliharaan akal, pemeliharaan keturunan, dan pemeliharaan harta benda. Peningkatan kesejahteraan yang dialami anggota berbeda-beda. Secara umum terjadi peningkatan kesejahteraan yang diukur dari kelima indikator tersebut.
\end{abstract}

Kata kunci: Pembiayaan, Baitul Maal wat Tamwil, Kesejahteraan

\section{PENDAHULUAN}

Perkembangan ekonomi syariah di Indonesia mengalami pertumbuhan yang sangat cepat dan masif, baik dari akademis maupun dalam praktek masyarakat di lapangan. perkembangan studi ilmu ekonomi syariah/islam dari kajian akademis bisa 
kita melihat dari banyaknya perguruan tinggi yang membuka program studi ekonomi syariah, hukum ekonomi syariah maupun perbankan syariah. Kemudian juga banyaknya kajian-kajian para tokoh ekonom islam, komunitas mahasiswa ekonomi syariah dan lainnya. Jika dilihat dalam perspektif praktek di lapangan bisa dilihat dengan mulai berdirinya lembaga-lembaga perbankan maupun lembaga keuangan syariah non-bank yang ada di Indonesia. Perkembangan industri perbankan syariah di Indonesia, pada tanggal 1 Februari 2021 telah beroperasi nya Bank Syariah Indonesia (BSI) yang merupakan gabungan dari tiga bank syariah BUMN yakni BRI Syariah, Mandiri Syariah dan BNI Syariah.

Dalam perkembangan dan pertumbuhan lembaga keuangan syariah yang ada di Indonesia, diawali dengan berdirinya lembaga perbankan Bank Muamalat Indonesia (BMI) pada tahun 1991 yang merupakan satu-satunya perbankan syariah di Indonesia yang mampu bertahan pada guncangan krisis moneter pada tahun 1998. Bank Muamalat Indonesia bisa bertahan terhadap guncangan krisis moneter karena dengan sistem syariah yang dianut mengharamkan perusahaan dari aksi spekulasi, yang di gadang-gadang sebagai penyebab krisis keuangan. Dengan bertahan nya Bank Muamalat Indonesia pada tahun 1998, dari kondisi ini dengan berbagai regulasi yang berlaku akhirnya memberikan ruang bagi perbankan konvensional untuk memberikan pelayanan berbasis syariah.

Dari data statistik perbankan syariah yang diambil dari data Otoritas Jasa keuangan (OJK) yang memberikan data perbankan syariah di Indonesia per Januari 2021 tercatat sebanyak 15 Bank Umum Syariah (BUS) yang tersebar di Indonesia dan terdapat sebanyak 20 Bank yang membuka Unit Usaha Syariah (UUS) yang memiliki banyak 2.068 kantor yang tersebar di seluruh wilayah Indonesia.

Dengan demikian, pertumbuhan perbankan syariah yang ada di Indonesia berkembang dengan cukup pesat, namun hal tersebut belum mampu menunjukan keberhasilan terhadap perkembangan lembaga keuangan syariah di Indonesia secara murni jika tidak diiringi dengan pertumbuhan lembaga keuangan syariah non perbankan lainnya. Sistem keuangan yang adil dan efisien dapat terwujud jika setiap lapisan masyarakat dapat terpenuhi keinginannya dalam berinvestasi dan berusaha. Namun kenyataannya perbankan syariah belum mampu menjangkau pada seluruh lapisan masyarakat di Indonesia, terkhusus pada masyarakat kelas menengah kebawah. Seharusnya pada lapisan masyarakat tersebutlah pertumbuhan dan perkembangan sektor usaha UKM, UMKM dan usaha kecil lainnya berada yang belum dijangkau oleh perbankan-perbankan syariah.

Dengan jangkauan lembaga perbankan syariah yang belum menyentuh pada lapisan masyarakat menengah ke bawah maka lembaga-lembaga keuangan syariah non perbankan sangat diperlukan peranannya dalam memberikan permodalan dalam meningkatkan kesejahteraan masyarakat. Salah satu lembaga keuangan mikro syariah (LKMS) non perbankan yakni Baitul Maal Wat tamwil (BMT) Syariah. Dengan adanya BMT Syariah diharapkan dan dinilai mampu menyentuh dan menjangkau masyarakat menengah ke bawah karena peran dan fungsi BMT Syariah salah satunya yakni melakukan pembinaan dan pendanaan berdasarkan sistem dan akad syariah serta keberadaan BMT Syariah dengan berbagai operasionalnya mampu mendorong perkembangan usaha masyarakat rumah tangga.

Dengan adanya peran dan fungsi ini menegaskan arti penting dari prinsip-prinsip syariah pada BMT Syariah dalam kehidupan bermasyarakat. BMT Syariah diharapkan tidak hanya sekedar menyelesaikan permasalahan permodalan pada usaha masyarakat tetapi juga tentunya membantu masyarakat dalam menghindari sistem rentenir, suku bunga (riba) yang sangat dilarang oleh Agama. 
Dalam Undang-Undang No. 25 tahun 1992 pasal 3 menyebutkan bahwa fungsi dan tujuan koperasi yakni memajukan kesejahteraan anggota pada khususnya dan masyarakat pada umumnya serta ikut membangun tatanan perekonomian nasional dalam rangka mewujudkan masyarakat yang maju, adil, dan makmur berlandaskan Pancasila dan Undang-Undang Dasar 1945. Dalam Undang-Undang tersebut bahwa dalam konsep pelaksanaan BMT yang merupakan lembaga keuangan non perbankan yang mempunyai badan hukum koperasi memiliki tanggung jawab dalam memberikan kesejahteraan terhadap anggotanya. Dengan harapan adanya keberadaan BMT Syariah melalui program pembiayaan yang disalurkan mampu membantu anggota BMT dengan tujuan akhir meningkatkan kesejahteraan anggota BMT Syariah tersebut.

Dalam penelitian ini objek yang akan diteliti yakni BMT Syariah Al-Azhaar yang merupakan satu satunya BMT yang beroperasi di Kota Lubuklinggau di Bawah naungan Pondok Pesantren Al-Azhaar Lubuklinggau. BMT Syariah Al-Azhaar telah membuktikan kepada masyarakat melalui kegiatan dan usahanya dalam melayani pengusaha mikro dan masyarakat kecil yang tidak mampu menjangkau dunia perbankan melalui jasa simpanan dan pinjaman yang berprinsip syariah. Hingga bulan Januari 2021 jumlah nasabahnya secara keseluruhan mencapai -+ 2980 Orang. Adapun gambaran perkembangan BMT Syariah ini pada saat ini telah memiliki tiga (3) cabang yang sudah berjalan dengan baik yakni di kota Lubuklinggau dan Kabupaten Musi Rawas.

Lahirnya BMT Syariah Al-Azhaar yakni adanya keprihatinan terhadap kondisi masyarakat ekonomi kelas menengah kebawah dalam menjangkau perbankan baik secara konvensional maupun syariah. Oleh karena itu diharapkan BMT Syariah Al Azhaar mampu berperan lebih aktif dalam memperbaiki kondisi dewasa ini dan menjadi solusi dari sistem perekonomian yang mengandung unsur syubhat dan ribawi. Peneliti sangat tertarik melakukan penelitian di BMT Syariah Al-Azhaar yang mulai beroperasi dari tahun 2011 dan memiliki perkembangan yang baik hingga tahun 2021 saat ini.

Sesuai dengan latar belakang yang telah dijabarkan diatas, maka dapat dirumuskan masalah yang akan menjadi acuan dalam penelitian ini yakni, bagaimana peran program pembiayaan pada BMT Syariah Al-Azhaar Kota Lubuklinggau dalam peningkatan kesejahteraan anggota dalam perspektif Maqoshid Syariah?

Peran didefinisikan sebagai sebuah aktivitas yang diperankan atau dimainkan oleh seseorang yang mempunyai kedudukan atau status sosial dalam organisasi maupun masyarakat. Peran berarti sesuatu yang dimainkan atau dijalankan. Dalam Kamus Besar Bahasa Indonesia (KBBI) mengartikan peran yakni seperangkat tingkah yang diharapkan dimiliki oleh orang yang berkedudukan di masyarakat. secara terminology peran merupakan seperangkat tingkah yang diharapkan dimiliki oleh yang berkedudukan di masyarakat.

Dalam bahasa Inggris peran disebut dengan rore yang definisinya adalah person's task or duty in undertaking". Maksudnya yakni tugas dan kewajiban seseorang maupun kelompok dalam suatu pekerjaan maupun usaha. Peran dapat diartikan sebagai suatu perangkat tingkat yang sangat diharapkan dimiliki oleh orang yang berkedudukan dalam masyarakat maupun organisasi.

Menurut UU No. 10 tahun 1998 tentang perubahan UU No. 7 tahun 1992 tentang perbankan, menyebutkan bahwa pembiayaan berdasarkan prinsip syariah adalah penyediaan uang atau tagihan yang dipersamakan dengan berdasarkan persetujuan atau kesepakatan antara bank dan pihak lain yang mewajibkan pihak yang dibiayai untuk mengembalikan uang atau tagihan tersebut dalam jangka waktu tertentu sesuai dengan kesepakatan dengan imbalan bagi hasil.

Jika dalam Lembaga Keuangan Mikro jika dihubungkan dengan kata syariah, maka dapat kita pahami bahwa lembaga keuangan mikro syariah (LKMS) merupakan badan yang melakukan kegiatan-kegiatan dibidang keuangan dengan menghimpun 
ataupun mengumpulkan dana dari masyarakat yang akan dikelola dan menyalurkan dana tersebut kembali kepada nasabah atau masyarakat. Dewasa ini banyak berdiri Lembaga Keuangan Mikro Syariah (LKMS) diantaranya Baitul Maal Wat Tamwil (BMT) Syariah, Koperasi Syariah, Pegadaian Syariah, Asuransi Syariah dan lainnya.

Baitul Maal Wat Tamwil berasal dari dua kata yakni Baitul Maal dan Baitul Tamwil. Baitul Maal bergerak pada usaha-usaha penghimpunan dana dan penyaluran dana non profit seperti zakat, infaq, shodaqoh sedangkan Baitul tamwil usaha yang mengarah pada penghimpunan dan penyaluran dan yang bersifat komersial. Baitul tamwil juga dapat berarti rumah penyimpanan harta milik pribadi yang dikelola oleh lembaga. Lembaga ini didirikan dengan maksud untuk memfasilitasi kalangan masyarakat menengah ke bawah yang tidak tersentuh oleh layanan perbankan.

BMT Syariah memiliki peranan dan fungsi dalam operasional diantaranya sebagai berikut:

a. Menjauhkan masyarakat dari pada praktek ekonomi yang bertentangan ketentuan islam. Disini BMT Syariah harus mampu dalam mengedukasi masyarakat tentang perekonomian syariah.

b. Memberikan pendanaan dan pembinaan pada usaha kecil. BMT Syariah dalam hal ini bukan hanya sekedar memberikan pembiayaan permodalan kepada nasabah atau masyarakat melainkan juga harus melakukan pendampingan, pembinaan serta penyuluhan dan pengawasan terhadap usaha yang dilakukan oleh masyarakat/nasabah.

c. Melepaskan masyarakat dari praktek yang berkembang di masyarakat terhadap rentenir. BMT Syariah dalam hal ini mampu memberikan layanan yang baik dan profesional dan tidak melakukan pelayanan yang memberatkan nasabah tetapi sesuai dengan prosedur yang ada sehingga dengan pelayanan yang baik masyarakat yang tadinya menggunakan jasa rentenir menjadi menggunakan jasa BMT Syariah.

d. Menjaga keadilan ekonomi masyarakat dengan distribusi yang merata. BMT Syariah harus mampu melakukan pemerataan skala prioritas atas nasabah/masyarakat yang memerlukan pelayanan lebih dari BMT.

BMT Syariah yang merupakan lembaga keuangan non perbankan yang memiliki sifat sosial dan bisnis dalam rangka memperbaiki perekonomian umat dan masyarakat, sehingga dana yang telah terhimpun dari masyarakat ataupun anggota harus kembali disalurkan kepada anggota melalui pembiayaan. Produk pembiayaan yang diberikan oleh BMT Syariah memiliki orientasi dalam meningkatkan dan mengembangkan usaha anggota sehingga meningkatkan pendapatan anggota BMT. Sasaran pembiayaan oleh BMT Syariah adalah semua sektor ekonomi yang halal. Seperti sektor pertanian, perkebunan, UMKM, Usaha Kecil, perdagangan dan jasa.

Ada berbagai pembiayaan yang bisa dilakukan oleh BMT yang mena mengacu pada dua jenis akad yakni syirkah dan jual beli. Dalam pelaksanaannya kedua jenis akad tersebut dikembangkan dengan kebutuhan yang perlukan oleh BMT Syariah dan anggotanya. Diantaranya pembiayaan yang sudah sering dijalankan oleh BMT Syariah secara umum sebagai berikut, Pembiayaan Murabahah, Pembiayaan Mudharabah, Pembiayaan Musyarakah, Pembiayaan Qard Hasan, dan Pembiayaan bai' bi tsaman ajil. BMT Syariah juga mengelolah dana sosial non profit seperti zakat, infaq, shodaqoh dan wakaf yang dalam hal ini BMT Syariah berfungsi sebagai amil.

Dalam islam memaknai kesejahteraan dengan istilah falah. Falah berasal dari kata kerja dalam bahasa Arab yakni aflaha yuflihu yang berarti kemuliaan, kesuksesan dan kemenangan dalam hidup. Falah secara istilah dapat didefinisikan sebagai kesejahteraan seimbang (holistik) antara beberapa dimensi yakni material, individu sosial dan kesejahteraan di kehidupan dunia dan akhirat. Kesejahteraan dapat terwujud 
apabila terpenuhi kebutuhan-kebutuhan hidup manusia secara seimbang sehingga tercapai maslahah.

Maslahah merupakan segala bentuk tentang keadaan, baik dalam keadaan material dan nonmaterial yang mampu meningkatkan manusia dalam kedudukannya sebagai makhluk yang mulia. Islam mengartikan kesejahteraan berdasarkan pandangan secara konfrehensif, yang mencangkup dua pengertian yakni: 1).Kesejahteraan seimbang (holistik), yakni kecukupan materi yang didukung oleh terpenuhinya kebutuhan spiritual dan sosial. Manusia sebagai makhluk yang terdiri dari unsur fisik dan jiwa, sehingga kebahagiaan haruslah menyeluruh antara kebutuhan kedua hal tersebut. Manusia adalah individu yang merupakan bagian dari lingkungan sosial sehingga manusia akan bahagia jika menjaga keseimbangan antara individu dan sosial lingkungannya. 2).Kesejahteraan dunia dan akhirat. Manusia tidak hanya hidup di alam dunia saja tetapi juga akan ada kehidupan setelah kematian (akhirat). Kesejahteraan dalam pandangan Islam tidak hanya dinilai dengan ukuran material saja melainkan juga dinilai dengan ukuran nonmaterial yang meliputi, terpenuhinya kebutuhan spiritual, terpeliharanya nilai-nilai moral, dan terwujudnya keharmonisan sosial.

Menurut Imam As-Syatibi bahwa kesejahteraan adalah terpenuhinya maslahah dasar kebutuhan kehidupan manusia yang terdiri dari pemeliharaan lima hal yakni, agama (Dien), akal (aql), harta (maal), jiwa dan keturunan (Nasl), dan jiwa (Nafs). kebutuhan dasar manusia tersebut merupakan kebutuhan dasar mutlak yang harus dipenuhi, apabila ada salah satu kebutuhan tersebut tidak terpenuhi maka kebahagiaan hidup tidak dapat tercapai secara sempurna. Kesejahteraan dalam perspektif individu dan sosial meliputi yakni, kebutuhan dasar, kesenangan dan kenyamanan serta kebutuhan kemewahan. 1).Kebutuhan Dasar (Dharuriyat) yakni kebutuhan dasar yang wajib terpenuhi, apabila kebutuhan ini tidak terpenuhi maka kebahagiaan dunia akhirat akan terancam. 2).Kebutuhan kesenangan dan kemewahan (Hajiyat) adalah sesuatu yang dibutuhkan untuk menghilangkan kesempitan yang dapat menyebabkan kesulitan dan kesukaran dalam melaksanakan suatu kewajiban, tetapi kesukaran tersebut tidak sampai apada tingkatan dharuriyah. 3).Kebutuhan kemewahan (Tahsiniyyah) yaitu melaksanakan kebiasaan yang baik guna menghindari sesuatu yang dianggap kotor dan tidak baik menurut logika akal sehat yang tercakup dalam akhlakul Karimah.

Secara umum, seseorang akan dikatakan sejahtera apabila kebutuhan pokok/dasar terpenuhi. Dalam penelitian ini menggunakan pendekatan kelima hal tersebut sebagai indikator kesejahteraan yakni, agama, jiwa, akal, keturunan dan harta. Pendekatan kelima indikator tersebut dipilih karena lebih lengkap dibandingkan dengan indikator kesejahteraan lainnya dan juga indikator ini merupakan indikator pengukuran kesejahteraan dalam perspektif syariah.

\section{METODE}

Pada penelitian ini menggunakan metode dengan pendekatan kualitatif deskriptif dengan jenis penelitian studi kasus, sehingga penelitian yang dilakukan akan fokus pada suatu kasus tertentu untuk diamati secara cermat kemudian dianalisis, kasus yang dimaksud bisa berupa tunggal atau jamak. Analisis dalam penelitian ini adalah peran pembiayaan BMT Syariah Al-Azhaar Kota Lubuklinggau dalam peningkatan kesejahteraan anggota penerima pembiayaan. Teknis analisis data yang akan digunakan yaitu menggunakan reduksi data, penyajian data dan verifikasi data serta kesimpulan, dari hasil reduksi dan penyajian data akan dianalisis dan akan dideskripsikan dalam bentuk uraian yang jelas. 


\section{HASIL DAN PEMBAHASAN}

Baitul Maal Wat Tamwil (BMT) Syariah Al-Azhaar dibawah naungan Koperasi Jasa Keuangan Syariah Simpan Pinjam Kota Lubuklinggau berdiri pada tahun 2011 dengan beberapa latar belakang salah satunya adalah melihat kondisi prihatin terhadap ketidakadilan nya ekonomi di masyarakat khususnya masyarakat menengah ke bawah. Sistem ekonomi kapitalis yang telah tertanam dan menggurita dalam semua tatanan kehidupan masyarakat sehingga sulit untuk meningkatkan perekonomian masyarakat kelas bawah. BMT Syariah Al-Azhaar Lubuklinggau Sejak berdiri hingga tahun 2021 tetap eksis dalam melayani masyarakat dengan motto "be save be true be a solution" BMT Syariah Al-Azhaar memiliki kantor pusat di Jl. Yos Sudarso No. 13 Rt 03 Kelurahan Taba Jemekeh Kecamatan Lubuklinggau Timur I Kota Lubuklinggau.

Adapun profil dan legalitas dari BMT Syariah Al-Azhaar Kota Lubuk Linggau yaitu:

Nama Koperasi $\quad$ : Koperasi Jasa Keuangan Syariah BMT Syariah Al-Azhaar

Kelompok Koperasi : KJKS Simpan Pinjam

Tahun Berdiri : 2011

Akta Notaris : Harijanto Tjiwidjaja, SH .

Nomor $\quad: 79$ tanggal 24

No. Badan Hukum : Nomor : 00011a/Bh/Vii.8/2011

TDP : 061226400404

SIUP $\quad: 556 / 06-12 /$ SIUP/XII/2011

ITU $\quad: 001 / \mathrm{ITU} / \mathrm{KPP} / \mathrm{XII} / 2011$

NPWP : :03.143110.9-303.000

Alamat Lengkap : Jl. Yos Sudarso No. 13 RT 3 Kelurahan Taba Jemekeh Kecamatan Lubuklinggau Timur I Kota Lubuklinggau

No./Telp. $\quad$ : : (0733) 321103/ Hp. 0822-8050-8600

E-mail : : bmts_al-azhaar@gmail.com

BMT Syariah Al-Azhaar Kota Lubuklinggau memiliki Visi yakni "mewujudkan budaya bisnis yang jujur. Amanah dan syariah serta berorientasi pada pemberdayaan ekonomi rakyat yang berkeadilan menuju masyarakat yang sejahtera lahir dan batin" sedangkan Misi BMT Al Azhaar Kota Lubuklinggau yakni;

a. Membangun sistem ekonomi yang mandiri dan berlandaskan Al-Qur'an dan Sunnah terhindar dari transaksi ribawi

b. Memberikan pembiayaan usaha dengan pola infaq dan pola margin bagi hasil

c. Memberikan margin bagi hasil yang adil bagi penabung (shahibul maal) dengan pembagian yang transparan

d. Memberikan kredit kepemilikan arang dengan sistem murabahah

e. Memberikan talangan haji dan umroh yang barokah

f. Menyiapkan masa depan yang barokah dengan dana pensiun dan asuransi pendidikan

g. Memberikan pelayanan yang islami, sepenuh hati dan bersahabat. ${ }^{1}$

Struktur Organisasi pada BMT Syariah Al-Azhaar Kota Lubuklinggau adalah sebagai berikut:

\footnotetext{
${ }^{1}$ Ah Mansur, "Dokumentasi Profil BMT Syariah Al-Azhaar” (Lubuklinggau, 2021).
} 


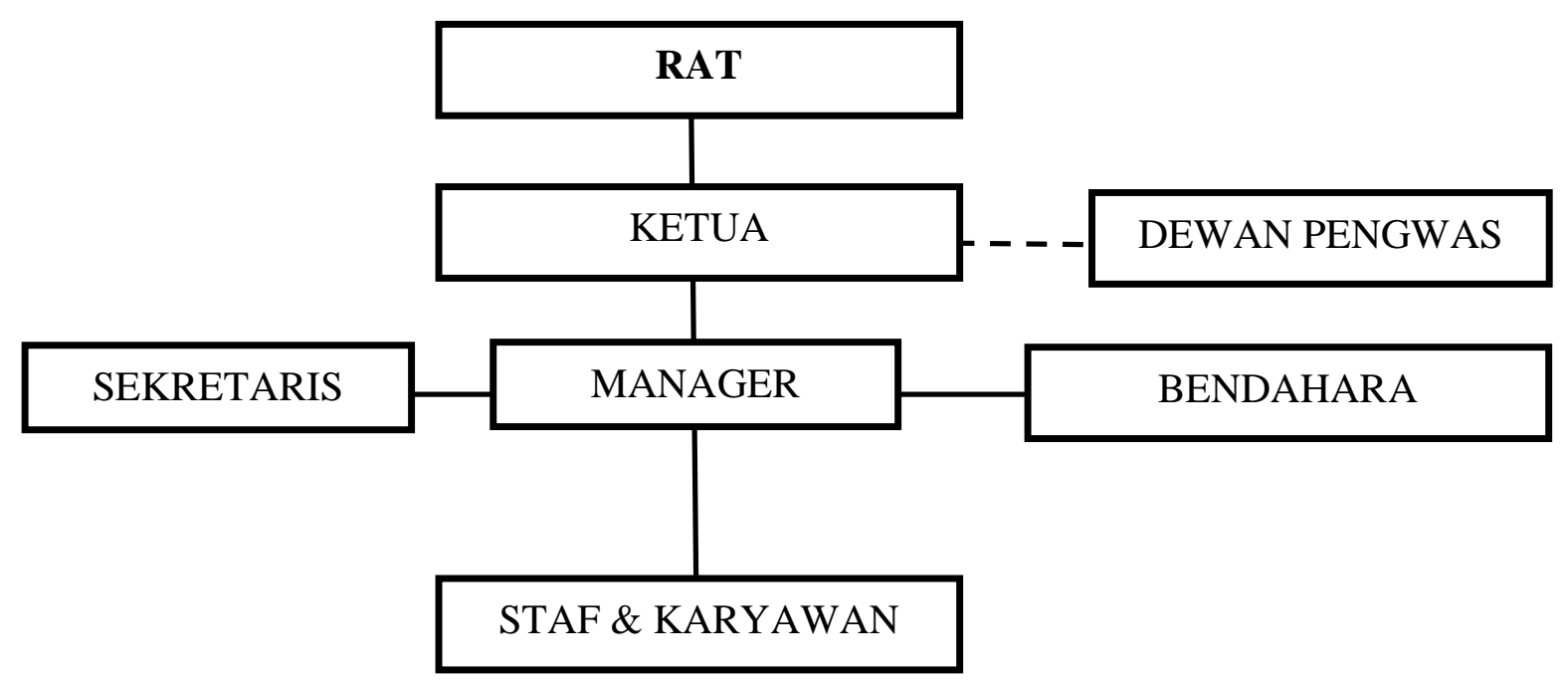

Berdasarkan Struktur organisasi pada BMT Syariah Al-Azhaar Kota Lubuklinggau yang dipimpin oleh Bapak Dr. KH. Ahmad Mansur, SE., M.Pd.I. Posisi Sekretaris Ibu Sari Inten sedangkan bendahara Ibu Koriah Ab, S.Pd.I. Kemudian terdapat dewan pengawas yakni Bapak Agus Salim, M.Pd.I dibantu oleh Bapak Zuhri, S.Sos.I M.Pd. yang secara umum memiliki tugas memastikan operasional BMT Syariah Al-Azhaar ini berjalan sesuai dengan aturan Syariah. Kemudian Bapak Herwansyah M.Pd.I sebagai pengawas internal (pengawas administrasi dan keuangan), bertugas dalam memastikan pelaksanaan administrasi BMT Syariah berjalan sesuai dengan SOP dan dari sisi pengawasan keuangan bertugas mengawasi transaksi sesuai dengan peruntukannya dan memenuhi prinsip audit.

Secara umum, manajer pada BMT Syariah Al-Azhaar memiliki peran dan fungsi yakni memimpin operasional BMT sesuai dengan tujuan dan kebijakan yang sudah dibuat oleh pengurus, kemudian membuat rencana kerja tahunan, bulanan dan mingguan yang meliputi rencana pemasaran, rencana pembiayaan, rencana biaya operasi, rencana keuangan dan laporan penilaian kesehatan BMT. Posisi manajer sendiri dijabat oleh bapak Aditya A. Pamungkas, SE. dibantu oleh beberapa karyawan lainnya.

Secara umum BMT Syariah Al-Azhaar Kota Lubuklinggau memiliki beberapa produk yang terdiri dari:

\section{Simpanan-simpanan}

Produk simpanan ini terdiri dari beberapa jenis yakni; 1) simpanan pokok, 2) simpanan wajib, 3) deposito Syariah dan 4) simpanan sukarela untuk simpanan sukarela terdiri dari; a) Tanjah (Tabungan an Najah), b) Taslim (Tabungan Muslim), c) Tampan (tabungan Masa Depan) dan Tabsan (Tabungan Santri).

\section{Pembiayaan dana tunai syariah}

Pada produk pembiayaan ini yaitu pinjaman dana tunai kepada nasabah/anggota/non-anggota BMT Syariah Al Azhaar yang berprofesi sebagai pedagang atau wirausaha mandiri dengan skala mikro dan menengah. Akad yang digunakan pada produk ini yakni mudharrabah, dimana sistem bagi hasil ditentukan secara infaq, kesepakatan ini diambil antara pihak BMT Syariah dan peminjam pada saat akad, sebelum BMT Syariah Al-Azhaar menggulirkan pinjaman dilakukan survey terhadap kelayakan nasabah.

\section{Pembiayaan kredit kepemilikan barang}

Produk pembiayaan Ini yakni pembiayaan kredit kepemilikan barang elektronik ataupun furniture rumah tangga yang ditunjukkan bagi nasabah, anggota/non-anggota 
BMT Syariah. Akad yang digunakan adalah jual beli murabahah, dimana nasabah mengetahui secara jelas harga dan selisih harga barang yang dijual secara kredit oleh BMT Syariah Al-Azhaar dengan jangka waktu yang ditentukan dan sistem angsuran bulanan.

\section{Kartu kredit}

Produk ini berlaku hanya kepada anggota Yayasan Permata Nusantara yakni Guru dan Dosen, pegawai pada unit usaha baik yang tetap maupun tidak tetap dibawah yayasan. Produk ini sebagai bentuk apresiasi terhadap seluruh anggota Yayasan Permata Nusantara Al-Azhaar, BMT Syariah Al-Azhaar memberikan solusi kepada anggota untuk belanja tanpa menggunakan uang cash pada outlet dan toko di Naungan Yayasan Permata Nusantara Al-Azhaar.

\section{Produk Jasa pada BMT Syariah Al-Azhaar Lubuklinggau}

Produk jasa yang ditawarkan pada BMT Syariah Al Azhaar untuk Karyawan/Nasabah/Anggota/Non-Anggota yakni, Penjualan tiket pesawat domestik dan internasional, jasa travel, jasa wisata religi, rental mobil/bus, paket wisata religi, loket pembayaran tagihan belanja online, pembelian tiket kereta api dan pelayanan perjalanan umroh dan haji.

Dalam menggali informasi terkait dengan BMT Syariah Al-Azhaar Kota Lubuklinggau, dalam mencari data terkait penelitian ini, peneliti melakukan wawancara yang mendalam terhadap 10 orang yang merupakan anggota/nasabah pada BMT Syariah AL-Azhaar yang menerima produk pembiayaan dari BMT Syariah ini. Berdasarkan hasil penelitian dan data yang diberikan kemudian dilakukan analisis yang telah dilakukan, bahwa informan yang mengalami peningkatan terhadap pemeliharaan agama (Dien) dapat dilihat pada tabel berikut.

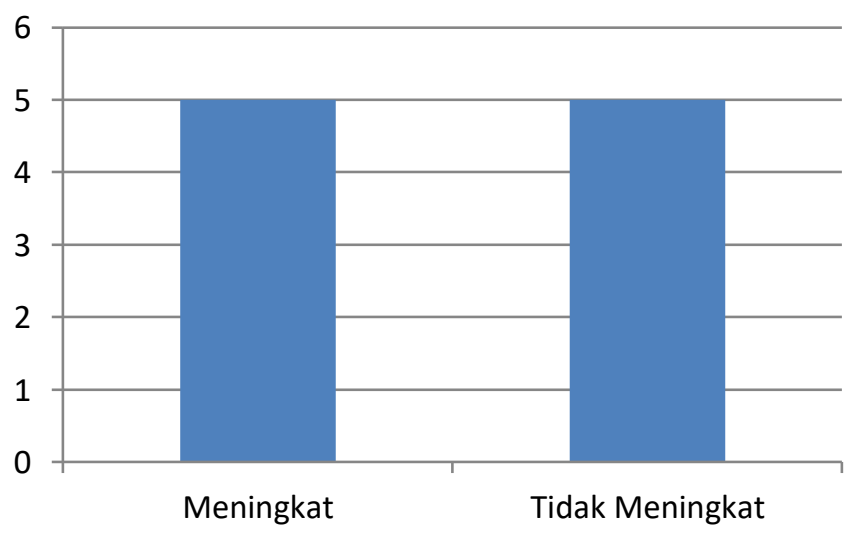

Peningkatan Nasabah dalam Pemeliharaan Agama

Grafik 1. Kondisi persebaran pemeliharaan agama

Berdasarkan Grafik 1 dapat diambil kesimpulan bahwa terdapat data perbandingan persentase 50:50, terdapat lima (5) nasabah yang mengalami peningkatan dalam pemeliharaan agama begitu juga dengan lima (5) anggota tidak mengalami peningkatan dalam pemeliharaan agama. Indikator dalam mengukur pemeliharaan agama pada penelitian ini yakni dengan melihat dari pengeluaran zakat, infaq dan shodaqoh yang dikeluarkan oleh Nasabah. Kelima nasabah yang mengalami peningkatan dalam pemeliharaan agama karena usahanya semakin berkembang sehingga pendapatan semakin meningkat sehingga timbul kesadaran dalam mengeluarkan zakat, infaq dan shodakoh. Kelima nasabah yang mengalami peningkatan pemeliharaan agama tersebut yaitu bapak Ikmal, Amin, Rasuli, Solikin dan Ibu Harnila. Kemudian nasabah yang belum mengalami peningkatan terhadap agama 
dikarenakan usaha yang digeluti ini belum berkembang sehingga hanya cukup untuk memenuhi kebutuhan sehari-hari. Dari kelima nasabah tersebut yakni ibu Zubaidah, Ibu Fitriyani, bapak Sobri, Kusnairi dan Andi.

Grafik 2 dibawah ini merupakan informasi yang didapat dari wawancara yang dilakukan kepada 10 orang tersebut terkait pemeliharaan jiwa didapat informasi gambarannya yakni;

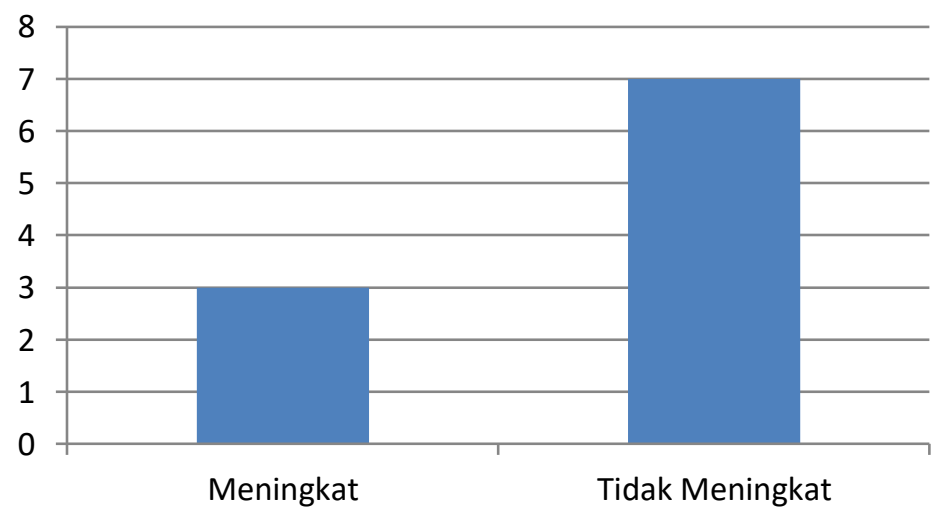

- Peningkatan Nasabah dalam

Pemeliharaan Jiwa

Grafik 2. Kondisi Persebaran dalam pemeliharaan Jiwa

Berdasarkan data yang diperoleh dari wawancara yang dilakukan, data yang didapatkan yakni pada Grafik 2, tersebut dapat dilihat bahwa dari 10 nasabah yang mendapatkan pembiayaan pada BMT Syariah Al-Azhaar, terdapat 3 (tiga) nasabah yang mengalami peningkatan dalam pemeliharaan jiwa sedangkan tujuh (7) nasabah lainnya tidak dan belum mengalami peningkatan. Indikator yang bisa dilihat dari pemeliharaan jiwa yakni melihat kemampuan nasabah dalam memenuhi kebutuhan pokok sehari-hari dan kemampuan nasabah dalam menjaga kesehatan. Dari 3 nasabah yang mengalami peningkatan dalam pemeliharaan jwa yakni dalam menjaga kesehatan. Nasabah yang mengalami peningkatan dalam pemeliharaan jiwa yaitu bapak Solikin, Rasuli dan Bapak Amin. Bahkan bapak Amin telah mengikuti program BPJS Kesehatan demi menjaga jiwa di masa depan. Adapun tujuh orang lainnya yang tidak mengalami peningkatan dalam pemeliharaan jiwa yakni Bapak Andi, Sobri, Ikmal, Kusnairi Ibu harnila, Zubaida dan Fitriyani, pada tujuh nasabah tersebut belum mengalami kenaikan pemeliharaan jiwa terdapat beberapa indikator yang bisa dilihat salah satunya yakni hasil pendapatan usaha nya belum begitu berkembang sehingga hanya mampu untuk memenuhi kebutuhan hidup sehari-hari.Kemudian pada hasil wawancara dan data yang dihasilkan pada pemeliharaan akal, adalah:

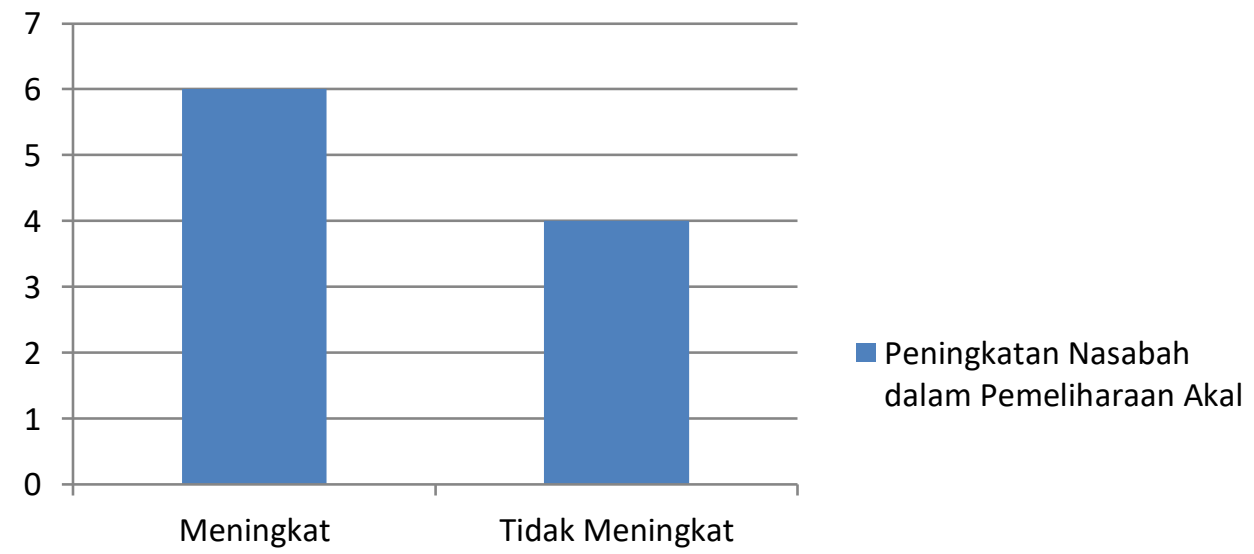

Grafik 3. Persebaran dalam pemeliharaan Akal 
Pada Grafik 3 bisa kita ambil gambaran bahwa ada persentase 60:40 \% nasabah yang mengalami peningkatan pemeliharaan akal. Terdapat 6 nasabah yang mengalami peningkatan dan 4 nasabah yang belum dan tidak menglami pemeliharaan akal. Indikator yang bisa dilihat pada peningkatan dalam pemeliharaan akal dalam penelitian ini diukur dengan melihat perkembangan kemampuan nasabah dalam mengembangkan usahanya yakni dengan inovasi dan kreativitasnya. Nasabah yang mengalami peningkatan kesejahteraan dalam hal ini pemeliharaan akal yakni bapak Bapak Ikmal, Bapak Andi, Ibu Harnila, Ibu Zubaidah, Bapak Sobri, dan Bapak Kusairi sedangkan yang lainnya belum mengalami peningkatan pemeliharaan akal. Kemudian juga pada data pada pemeliharaan keturunan, hasil dari wawancara yang didapat adalah:

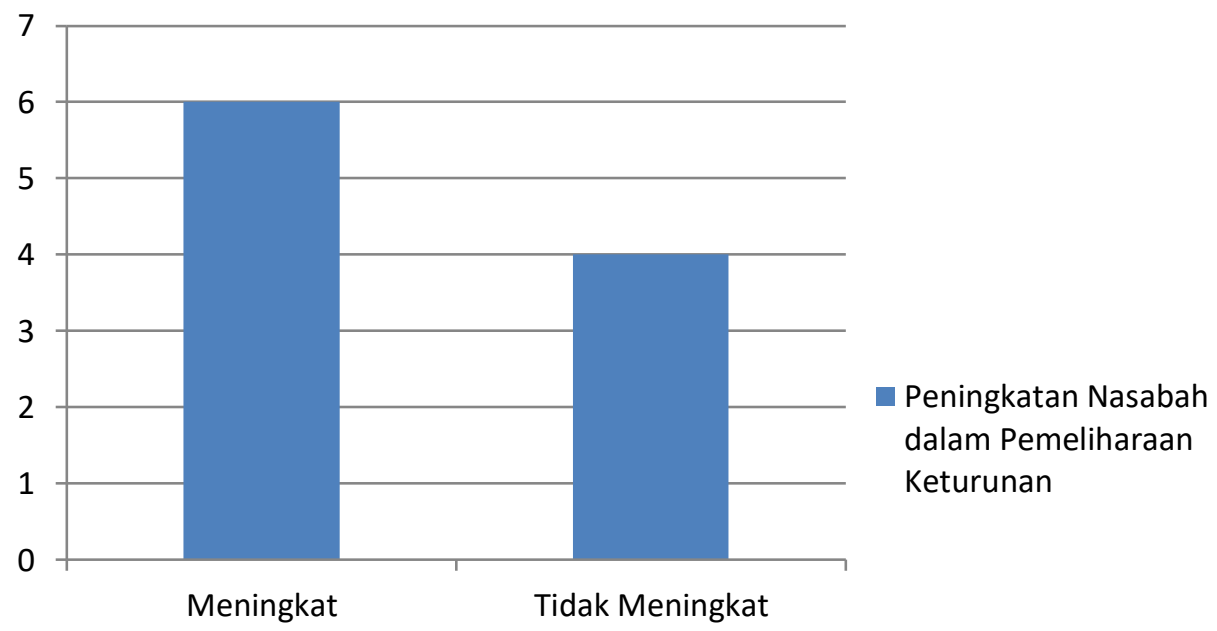

Grafik 4. Persebaran dalam pemeliharaan Keturunan

Sesuai dengan Grafik 4 bahwa juga terdapat persentase sebanyak 60:40 \% dalam meningkatnya pemeliharaan keturunan. Dalam melihat data ini, indikator yang dipakai dalam menentukan peningkatan dari pemeliharaan keturunan adalah melihat dari kemampuan nasabah atau orang tua dalam meningkatkan pendidikan anaknya ke jenjang yang lebih tinggi. Adapun peningkatan para nasabah setelah menerima pembiayaan dari BMT Syariah Al-Azhaar Kota Lubuklinggau. Diantaranya Bapak Ikmal, yakni dengan menyekolahkan anaknya ke tingkatan yang lebih tinggi, kemudian bapak Andi dengan memberikan fasilitas kursus tambahan diluar waktu sekolah untuk menambah soft skill anaknya. Lalu Ibu Harnila dengan memasukan anaknya di Pondok Pesantren Al-Azhaar supaya anaknya paham terkait dengan agama, dan ada juga yang mempersiapkan masa depan anak dengan memberikan bekal usaha dagangan. Terjadinya peningkatan dalam pemeliharaan keturunan disebabkan adanya kesadaran informan untuk mempersiapkan masa depan anak dengan baik. Informan yang mengalami peningkatan dalam pemeliharaan keturunan tersebut adalah Bapak Ikmal, Bapak Andi, Ibu Harnila, Ibu Zubaidah, Bapak Sobri, dan Bapak Kusnairi. Pada hasil wawancara mengenai pemeliharaan harta, hasil yang didapat pada Grafik 5.

Berdasarkan Grafik 5. bahwa terdapat sembilan (9) nasahab mengalami peningkatan dalam pemeliharaan harta dan hanya satu (1) orang nasabah tidak mengalami peningkatan dalam pemeliharaan harta. Peningkatan pemeliharaan harta dalam penelitian ini erat kaitannya dengan jenis usaha yang dimiliki oleh nasabah dan alasan nasabah untuk mengajukan pembiayaan ke BMT Syariah Al-Azhaar Lubuklinggau. Hanya satu nasabah yang tidak mengalami peningkatan harta merupakan seorang ibu yang berjualan gorengan di pinggir jalan. Berdasarkan keterangan yang didapatkan dari informan, hasil penjualan gorengan tidak mengalami peningkatan meskipun telah menerima pembiayaan dari BMT Syariah AL-Azhaar. Hal itu 
dikarenakan jumlah pembeli tidak meningkat walaupun Ibu Harnila telah menambah jenis gorengan, melakukan inovasi pada jualannya, mencari tempat strategis penjualan dan membeli perlengkapan penjualan. Alasan ibu Harnila mengajukan pembiayaan pada BMT AL Azhaar awalnya adalah digunakan untuk menambah modal pada usaha jual gorengan, yakni membeli alat dan bahan lainnya.

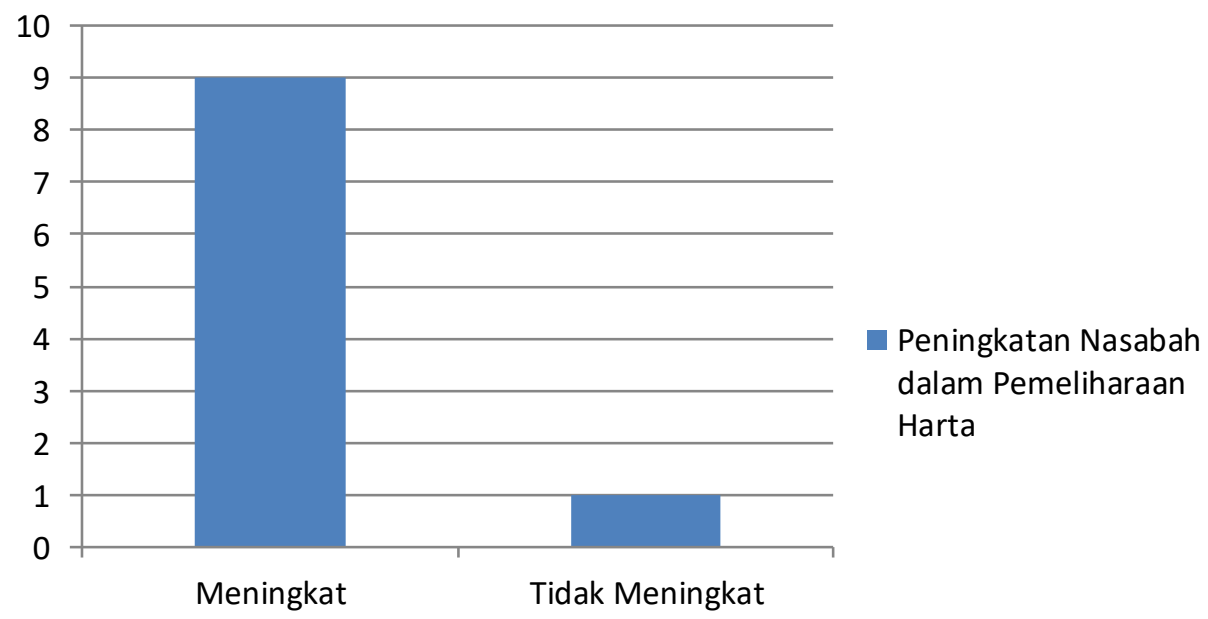

Grafik 5. Persebaran dalam pemeliharaan harta

Selain itu, tidak meningkatnya kesejahteraan nasabah dalam hal pemeliharaan harta adalah karena beliau mengaku satu-satunya sumber penghasilannya hanya berasal dari jualan gorengan, sedangkan kebutuhan keluarga sangat banyak. Keterangan mengenai penghasilan dari pedagang gorengan juga diperkuat oleh Ibu Zubaidah yang juga merupakan penjual gorengan di pasar kota Lubuklinggau, menurut buk Zubaidah karana saat banyak pesaing yang juga berjualan gorengan di pinggir jalan. Sedangkan sembilan informan yang mengalami peningkatan kesejahteraan dalam pemeliharaan harta sebabkan oleh hal yang berbeda-beda. Misalnya bapak Ikmal yang mengajukan pinjaman di BMT Syariah Al Azhaar dana yang dipinjam di kembangkan dalam usaha bengkelnya, kemudian bapak kusnairi juga mengajukan pinjaman di BMT digunakan untuk menambah modal pada penjualan sayur keliling dan informan lainnya.

\section{KESIMPULAN DAN SARAN}

\section{Kesimpulan}

Dari hasil pembahasan diatas dapat diambil kesimpulan bahwa, dengan adanya BMT Syariah AL-Azhaar Kota Lubuklinggau memberikan dampak dan berperan dalam meningkatkan kesejahteraan anggotanya. Dari kelima indikator kesejahteraan dalam islam, hampir seluruh nasabah mengalami peningkatan kelima aspek tersebut yakni, Agama, Akal, Keturunan, jiwa dan harta. Meningkatnya kesejahteraan yang dirasakan oleh anggota dengan meningkatnya pemeliharaan lima kebutuhan pokok sesuai maqashid syariah masing-masing.

Berdasarkan hasil pada tabel diatas bahwa terdapat 10 nasabah yang merupakan anggota BMT Syariah Al-Azhaar Kota Lubuklinggau yang mendapatkan pembiayaan dari BMT Syariah mengalami peningkatan yang berbeda-beda. Adapun peningkatan dari kelima indikator dintaranya: a).Peningkatan terhadap pemeliharaan agama sebanyak 5 Nasabah, b).Pengikatan pada pemeliharaan jiwa sebanyak 3 Nasabah, c).Peningkatan pada pemeliharaan akal sebanyak 6 Nasabah, d).Peningkatan pada pemeliharaan keturunan sebanyak 6 Nasabah, e).Peningkatan terhadap pemeliharaan harta sebanyak 9 nasabah.

Sehingga dengan hadirnya BMT Syariah Al-Azhaar Kota Lubuklinggau 
memberikan dampak dan manfaat dari produk pembiayaan yang digulirkan nya sehingga meningkatkan pendapatan nasabah dan memberikan kesejahteraan kepada anggotanya.

\section{Saran}

Bagi nasabah/anggota yang menerima pembiayaan BMT Syariah Al-Azhaar Kota Lubuklinggau yang digunakan dalam mengembangkan usaha dagang diharapkan meningkatkan kapasitas jualannya serta berinovasi dalam usaha. Bagi pengelola BMT Syariah Al-Azhaar Kota Lubuklinggau diharapkan meningkatkan pertemuan rutin setiap bulannya kepada nasabah bisa dilakukan dengan pengajian dan ceramah agama. Hal ini selain untuk memper erat silaturahim juga meningkatkan pembinaan serta untuk mencari solusi bersama apabila ada kendala dan masalah yang timbul pada anggota sehingga ditemukan solusi, sehingga peningkatan kesejahteraan dapat tercapai secara maksimal.

\section{DAFTAR PUSTAKA}

Antonio, Syafii, and Hilman F Nugraha. (2013). Peran intermediasi sosial perbankan syariah bagi masyarakat miskin. Tsaqafah 9(1). 123-148.

Bisnis, Finansial. (2021). Bank Syariah Indonesa. diakses dalam https://Finansial.Bisnis.com/ Bank Syaiah Indonesia. Tanggal 15 Agustus 2021

Heri, Sudarsono. (2012) Bank dan lembaga keuangan syariah deskripsi dan ilustrasi. Edisi Ketiga. Ekonisia: Yogyakarta.

Indonesia, CNN. (2021). Lika-liku jalan berkerikil Bank Muamalat Indonesia. https://www.cnnindonesia.com/ekonomi/20180301235151-78-279840/lika-likujalan-berkerikil-bank-muamalat. diakses pada 14 Juli 2021

Indonesia, Kamus Besar Bahasa. (2011). Kamus besar bahasa Indonesia. Republik Indonesia

Jaya Bakri, Asafri. (1996). Konsep maqhasid syariah menurut Al-Syaitibi. PT. Raja Grafindo Persada: Jakarta.

Jayadi, Ahkam. (1996). Penerapan Undang-Undang Nomor 25 Tahun 1992 pada koperasi.

Mansur, Ah. (2021). Dokumentasi profil BMT Syariah Al-Azhaar. Lubuk linggau

Muhammad Syafi'i., \& Antonio. (2001). Bank Syariah teori dan praktik. Gema Insani: Jakarta.

OJK. (2021). Kanal syariah data dan statistik Perbankan Syariah. diakses https://www.ojk.go.id pada 20 Juli 2021

Pengkajian, Pusat. (2008). Pengembangan ekonomi islam (P3EI), ekonomi islam. PT. Raja Grafindo Persada: Jakarta

Soemitra, Andri. (2014). Bank \& lembaga keuangan syariah. Prenada Media: Jakarta.

Sugiyono. (2020) Metode penelitian kualitatif. Alfabeta: Jakarta.

Suyoto. (2017). Peran Baitul Maal Wa Tamwil (BMT) dalam meningkatkan kinerja usaha rumah tangga di Purwokerto. JSSH (Jurnal Sains Sosial dan Humaniora), 1(1), 1-10.

Torang, Syamsir. (2013). Organisasi \& manajemen perilaku, struktur, budaya \& perubahan organisasi. Alfabeta: Jakarta. 